Issue no. $25 / 2018$

\title{
POLICY DESIGN FOR COMPETITIVENESS. A HETERODOX VIEW ON THE PRESENT DAY GOVERNANCE OF THE ROMANIAN ECONOMIC LIFE AND BUSINESS ENVIRONMENT
}

\author{
Monica BURCĂ-VOICU*, Horațiu DAN**, Mircea MANIU***1
}

\section{DOI:10.24193/OJMNE.2018.25.01}

\begin{abstract}
As the Romanian political outlook became much more clustered and therefore more predictable following the 2016 elections, though not clearer structured on left-right coordinates, the expectations of a sharper policy design and consequent actions of both micro and macroeconomic consistence were, and still are higher than ever in the country. Meanwhile, the obvious impact of a plethora of negative exogenous factors, emerging from EU and worldwide, induced new and unexpected types of constraints for the domestic economic policy framework. Within this juncture our research attempts to assess the present day situation, from a methodologically heterodox perspective. While the overall target of both political and economic consistence is a fixed one and consists in real EU convergence on a determined strategic horizon, the means (specific economic mechanisms) to reach this goal should be flexible and dynamic. Simply put the unsatisfactory outcomes of the last couple of decades induce this strong need to change methodological perspectives. First of all, we attempt to delineate, on historical coordinates, why the present state of the affairs and the governmental political economy that induced this state is inappropriate and is not serving the long quest for competitiveness of the Romanian economy within EU. Evaluating the growth potential of the economy on several layers and comparing stage results we try to point to creative solutions that would interlock public and private spheres and make a noticeable difference on the short run. In this endeavor we try to emphasize the delicate connection between the outlook of the economy and which institutional parameters of the economic culture and education would be relevant for the case of contemporary Romania. This paper would be only the inception of a larger research framework, meant to contribute with academic means to the overall economic policy design as well as refine the
\end{abstract}

$1^{*} \quad$ Dr. Monica Burcă-Voicu, Lecturer, monica.voicu@ubbcluj.ro; **Dr. Horațiu Dan, Lecturer, horatiu.dan@ubbcluj.ro; $* * *$ Dr. Mircea Maniu, Associate Professor, mircea.maniu@ubbcluj.ro, all three staff of Babeş-Bolyai University Cluj-Napoca. 
Issue no. $25 / 2018$

business environment governance procedures, an imperative must for competitiveness, sustainable growth and accelerated development of the country.

Keywords: business environment, competitiveness, economic policy, Romania

\section{Starting points}

This research has been mainly triggered by relatively recent events of mainly political consistence which generated a truly dramatic paradox of the Romanian economy's evolution during the last couple of years. The 2016 general elections paved the way to power to a social-democrat and liberal coalition that has a minimal parliamentary majority, but allowing the support of the governing process of such a manner that was valid only as an exception in this country. Meanwhile, despite the EU political turmoil, the present day international and domestic economic conjectures appear to favor the development of the domestic business environment in such a degree that Romania was in fact a growth champion of EU in 2016 and the 2017 macroeconomic outlook seems also to be placed under a good omen. It is obvious that under these conditions the rational expectations of both professional milieus and common people were that appropriate structural policies of strategic consistence could be taken now, allowing the country to make a significant developmental leap in the years to come and eventually to join the Eurozone as soon as possible. Unfortunately, even since the very inception of the new legislature the public discourse of the political establishment in power convey the message that nothing of the sort would happen soon, at least if one thoroughly interprets the obvious liabilities and less obvious assets in the evolution of the Romanian economic life, unfolding during the last year.

The above invoked rational expectations are usually built upon several endogenous and exogenous parameters of already historical consistency. We will tackle under these auspices only the endogenous ones, since we believe these are the most relevant for the case of economic policy we investigate. First of all, it is the so-called transition route, namely the period between the fall of the communist regime in December 1989 and the moment of joining the EU in January 2007. Secondly, we must acknowledge and elaborate on the intricacies and peculiarities of the path happening for already a decade within EU. But for a set of several reasons we believe that the present day bumpy journey of the Romanian economy cannot be revealed properly unless we point also to at least some of the features that 
Issue no. $25 / 2018$

were relevant for the pre-1989 economy and economic policy and which we believe that unfortunately still reverberate on the present day economic competitiveness and performance of the country. We try to conduct this investigation aware of the fact that what we call the free world evolved after WWII mostly on Keynesian trade coordinates of American inspiration (Mann, 2015), so we acknowledge the role of the government in specific moments of the economic history of a certain country, despite the overall liberal outlook of the international economy today. Therefore, the itinerary we have in mind to research this topic would like to permanently parallel the political approaches with the economic outcomes, both observed from strategic and tactical angles.

Whatever we will accomplish through this endeavor does make sense if predictable elements of economic policy could be forwarded at a later stage, or at least reasonable alternatives to be presented for public debate and assessment. We undertake this challenge only up to a point. Previous larger frameworks researches of the kind already taught us the lesson that straightly approaching the political elite from a purely academic research perspective, no matter how professionalized would be, never works properly, at least not in Romania. But when the discourse is methodologically focused on institutional building through enhancing various cultural layers that form the grounds of any developed society, the odds are that such a research could become in due time a much more pragmatic tool with economic policy consistence. As two reputed followers of Maslow and Sorokin, namely Dade and Ross point (2008) any society is driven forward by pioneers, those inner directed by new ideas. But they must coexist with the prospectors, namely those driven by success, material or/and social and settlers, those motivated by safety and obviously representing the bulk of a country's population. Our opinion is that at this point in its existence the Romanian society must find a proper cultural leverage in order to change the counterproductive, forged in time under various constraints, balance between these existing informal social contingents.

On July 26, 2017 Eric Maskin was awarded the honorary degree of doctor honoris causa of this university. It rewarded his outstanding contribution to the formulation of the Mechanisms Design Theory, a 2007 Nobel Prize honored research. Presenting this theory in a nutshell, professor Maskin explained how this reversed game theory was conceived focusing on strategic settings that ultimately allow the buildup of the necessary incentives, aggregated 
Issue no. $25 / 2018$

into a specific mechanism, provided the players act rationally. Such an exposure seems to epitomize the methodology we have in mind, where the clear objective of a fully EU convergent Romania could be reached starting with heuristic approaches of the kind Herman Kahn envisaged in his alternative scenarios, and ending with the kind of counter-modeling that seems necessary when the very sense of economic causality in place seems wrong. (Hogwood and Gunn, 2000) How otherwise can we make operational the above-mentioned triad - pioneers/prospectors/settlers - but through the culturally built triad of umpires/players/public, which actually stand for the mechanism components of the subsequent triad policy makers/entrepreneurs/citizens. It is in our view one of the few heterodox ways to deconstruct the decades established classic, orthodox economic mechanism that allowed and still allows weak institutions to function undisturbed, as a follow-up of a defective cultural outlook. (Fudulu, 2003)

\section{Brief diagnosis. Policy in retrospective}

The process of transition from the centrally planned economy to free market was difficult, bumpy and associated with an excessively entropic economic policy, differentiating the country from most of the other transition ones across Central and Eastern Europe. The so called "transformational recession", as Dăianu (2000) mentions, citing Kornai, was inevitable up to a certain point due to the fact that during the 80s Romania was the worst case of closed economy among socialist countries, with autarchic inflexions, witnessing a sui generis post Stalinist approach of the political economy of the time, this lethal combination of causes generating a major setback in the overall evolution of the Romanian economy and society. When starting the complex process of transition in the early 90 s the country took a peculiar "own patterned" path of getting rid of its totalitarian past, path that proved to be considerably more erratic than in comparable countries. The explanations for this situation could be traced both to the Romanian political and economic peculiarities of the interwar years as well to the distinguishing features of the Romanian communism, notably of Nicolae Ceauşescu's dictatorial regime during the 1980 s.

These kinds of considerations could be relevant triggering factors for analyzing the specifics of Romania's historical evolution in the comparative economic dynamics of inter- 
Issue no. $25 / 2018$

war years, communist epoch, transition and post-transition towards the present day. And they are a must within the context due to the necessity to explain rationally why the documented lack of overall performance of the country when benchmarked to rational expectations is due mostly to wrong economic policy above all. It might be also said that there is a view considering this gap (expectations-reality) is due to the fact that the over optimistic expectations of the population following the fall of the communism were generated by the obviously wrong positioning of the political establishment, sometime even of the professionalized circles (economists), that overemphasized features beyond reality, features definitely could have been interpreted as competitive and comparative advantage of the country. (Albu, 2010). Moreover, a strongly disciplined population, both by the grim experience of a tough police state and by the overall effect of the severe domestic consumer goods crisis during the late 80 s, was definitely prone to over rational expectations concerning the new economic system emerging in the 90s.

If one tries to peg the economic evolutionary framework to the governmental swap and succession to power since 1990, of social-democrats that were arguably former communists (1990-1996), a centre-right coalition (1996-2000), followed again by social democrats (2000-2004), to be followed by a Christian-democrat and liberal coalition (20042007), Christian-democrats (2008-2012), again social-democrats (2012-2015), a brief technocratic intermezzo (2015-2016) and again social-democrats since 2017, one cannot but observe a succession of conflicting policies, hardly consistent in message with the ideological affiliation of their promoters. Beyond the positive main trend steps, exogenously imposed by the necessity of creating a functional market economy as the Maastricht Treaty required, this could be interpreted as a continuous negative political cycle, which has undoubtedly influenced the overall performance of the country. Nevertheless, a peculiar note of caution is however valid in Romania too, as was the case in most of the Central and Eastern European countries, namely the fact that each government coming to power had to set its own policy and make adjustments in accordance with the legacy induced by the previous one and moreover to the "path dependency" generated by communist development occurring throughout the region for almost half a century. (Ehrenberg and Smith, 2012). In this context, one needs to acknowledge however that while the sluggishness of the economic 
Issue no. $25 / 2018$

reform could be largely attributed the insufficient competence of the political leaders and social managers, as some sources emphatically, even violently accuse (Bompa and Porojan, 2010), it seems to be more important to acknowledge that a generation of citizens lacking democratic experience and consequent free market knowledge, represented the most active and comprehensive delaying factor to reform.

With the exception of Romania, and to a certain extent neighboring Bulgaria, all of them started the switch towards market economy with radical policy makers in power, ideologically closer to the right, or at least willing to adopt appropriate shock therapies and sacrifice political petty populist tactics for the purpose o modernizing rapidly their countries. Was it a matter of institutional adequacy/inadequacy? While in terms of acquiring democratic institutions and long-time certified political procedures, this was easier to undertake for all the above-mentioned Romanian governments due to the plethora of European available models, coherently restructuring the economy was a much harsher process. The shrinking of the oversized industrial sector, while no alternatives were in place for the placement of the redundant industrial workforce, led to a counterproductive expansion of the agricultural sector that played the role of labor buffer. Meanwhile privatization and property ownership reforms were carried on at such a slow pace that real entrepreneurship effects, enabling a healthy private endogenous sector to exist, could not be observed. (Kallai and Maniu, 2007) The economic take-off was possible only following massive portfolio and foreign direct investments. That leaves an important open question: is the main debate about the soundness of the economic policy in contemporary Romania focusing enough on the regulation of the delicate balance between endogenous and exogenous factors?

We believe it is highly relevant to observe also how the professional environment reflects in time the need for radical change in terms of policy. From simple mimetic moves, to structural approaches embedded in the various angles transition took across CEE, (Aligică, 2009) the evolution of Romania seems peculiar from the standpoint of a certain evolutionary paradox. While the policy of most governments was heavily conjectural, regardless of the political affiliation of those in power, there is an obvious lack of continuity in major processes (privatization, foreign trade, state subsidies, public investment, etc.) that objectively induced the "hopping" process of the economy, with economic cycles that are still 
patterned above all on the political (4 years) cycles. In a time when technocratic moves (hopefully this should be interpreted as EU supranational governance) induce a trend of continuity in major economic processes (CAP policy, Euro adoption, use of structural funds, environmental policy, etc.) no matter of the EU's political consistency of the moment, quite the opposite happens in Romania. Balancing between the EU inspired economic governance, as the strategic economic rationale demands and the domestically political more comfortable tactical inertia of the status quo seems to be an endless counterproductive game of the domestic political establishment. (Drăgan, 2013).

It is a fact that such a deficient evolution has various kinds of generating reasons, but in our opinion without doubts solid cultural roots too. Cultures underline differences among people and nations and build identity through exclusivity and sometime adversity and opposition. One could notice the overlapping and complementarities of such concepts as cultures and civilizations: while cultures design a certain status, civilizations assign roles in the evolutionary process, as one of the most reputed Romanian cultural philosophers, namely Mircea Maliţa, describes the phenomenon. There are substantial differences between what we usually call national cultures and even deeper inside of each of them, there are different layers of it, enabling society to act constructively or quite the opposite in critical moments. The truly great culture is that able to act as a moderator of the economic, social and cultural performance. If one investigates the historical roots of the institutional approach in Romania, as Păun (2009) does, it will discover there is no significant opposition in this country to follow procedures and adopt institutions that were developed in time throughout the developed world, mostly in Europe. Therefore, we can say that the real de-institutionalization of the country, when it comes to the framework of the economy, occurred only during communism, but the impact was hugely damaging on the long run, up to the present.

If society functions mostly through a sum of transactions and we perceive the costs of those transactions according to the peculiarities of this differentiated socio-culture, Romania acquired its share from obviously different sources, or socio-cultural suppliers, if we may say so. To a certain extent assimilation and imitation occurred, but also adaptation of the industrial patterns that were present across most of the developed countries of Europe. Analysing the Romanian social and economic environment after 1989, one conclusion 
Issue no. $25 / 2018$

appears, both explicitly and in between the lines. During almost two decades, the endogenous political arena has displayed a relatively constant inability of its main forces (Parliament, Presidency, Government, political parties, trade unions, civil society, etc.) to agree on timing and sequencing of most important institutional reforms during transition. Therefore, progress in economic and social reforms has been significantly slower in Romania than in comparable countries in the region. The initial Romanian advantage of "starting from scratch", imposing to a certain degree the re-thinking all institutions and socio-cultural aspects of life in Romania (Aligică, 2003) could be evaluated or at least branded more or less as a failure. And this failure has been the most instrumental tool in keeping alive a level of economic culture that is contradictory to the realities of the present-day world economy.

Meanwhile, to soften somehow this gloomy picture, we can observe a sort of continuity in the so called exo-genesis of the modernization process, which could be traced to topics generating national consensus, not only on such tracks as EU integration and NATO belonging, the already classical Romanian consensual features. At this point it might that the main problem of generating critical mass to expand the exogenous trigger to the realm of the economic life could be considered neither the lack of will, nor the educational setbacks, but the defective approaches to properly interlocking institutions. (Brătianu et al. 2010) If one is tempted to associate all kinds of negative economic effects (corruption, irrational state monopoly, partisan developmental policies, etc.) with the legacy of the communist regime, culturally still alive, laundering the present day political approach, that would be a huge mistake in our opinion. But if we add to this judgment the assessment that during the communist regime the country faced almost the same liabilities, but less obviously socially perceived due to the lack of basic freedoms, it seems rational to say that the present day process of cultural change, assimilation of perennial values and overall progress, grounded on the freedom to choose the dominant culture, as Norberg puts it (2010), simply failed in Romania on the short run. The overall modernization of the country has been triggered, but is lacking consistency mainly due to the lack of adequate cultural support. 
Issue no. $25 / 2018$

\section{Romanian competitiveness - an international comparative perspective}

In a present day global highly competitive environment, national competitiveness is one of the central issues on the agenda of governments, especially those of emerging economies, with policymakers striving to design and implement efficient measures that would boost competitiveness, thus paving the way for sustainable growth. It is without doubt a central issue in the specific case of EU's economic policy due to the multiple consequences concerning the extremely important issue of economic convergence. (Dierx et al., 2017) Romania's case follows this pattern, at least in a formal, declarative way, as the objective of increasing competitiveness is present in virtually all governmental programs and major strategies of the last decades. However, as our analysis shows, Romanian competitiveness policy has often been inconsistent and inefficient, generating suboptimal results, although the economy has enjoyed a rather long period of accentuated, consumption based, economic growth. Nevertheless, in order that our economy and society transcends this mainly consumption-led phase and ensure that growth is here to stay at least on a medium or even on a long-term perspective, increasing competitiveness, both general and in relevant economic sectors, is crucial.

One of the most popular measurements of competitiveness is provided by the Global Competitiveness Index (Schwab and Sala-i-Martin, 2016), a comprehensive research developed by the World Economic Forum, aimed at identifying, quantifying and internationally ranking competitiveness and all its functional elements, thus constituting an extremely valuable tool for deeper analysis, enhanced policy design and consequently improved implementation. Analyzing the Global Competitiveness Index (GCI) data, we notice that, after previous improvements, Romanian relative competitiveness is in decline (Graph 1), currently ranking $68^{\text {th }}$ out of 137, behind other Central Eastern European countries like Poland (ranked $39^{\text {th }}$ ), Bulgaria (ranked $49^{\text {th }}$ ), Slovakia (ranked $59^{\text {th }}$ ) or Hungary (ranked $\left.60^{\text {th }}\right)$. 
Graph 1: Romania's competitiveness ranking (Global Competitiveness Index)

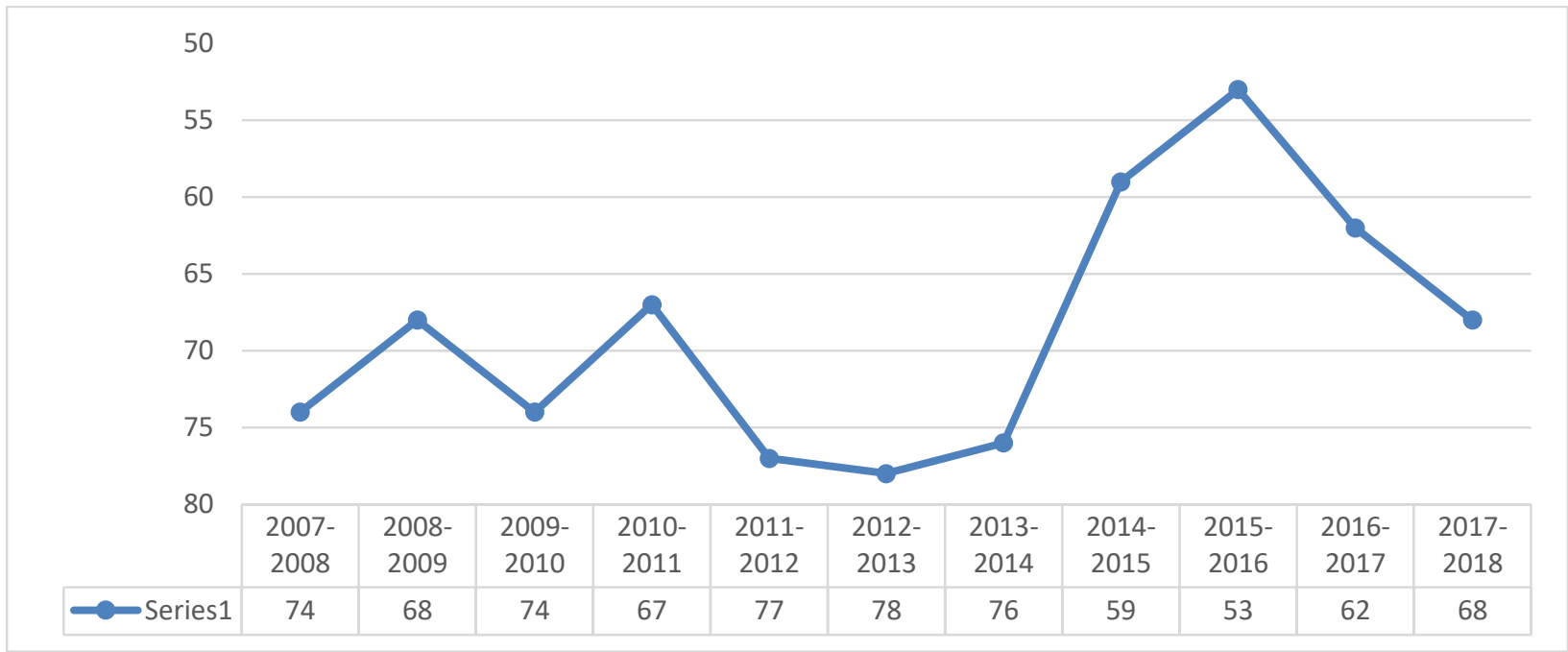

Source: Own plotting based on GCI data

A closer look at the values of the 12 pillars that aggregate Romania's competitiveness rank reveals that institutions, infrastructure, business sophistication and innovation are the worst performers. In order to fully understand this situation, the analysis must be performed in the light of at least the following facts:

(1) the GCI identifies high favoritism in decisions of government officials, high wastefulness of government spending, high burden of government regulation, low efficiency of legal framework in challenging regulations, high diversion of public funds and low levels of public trust in politicians, all of which potentially and effectively generate, among other factors, severe inefficiencies in the policy design and implementation process;

(2) the poor condition of infrastructure, especially when it comes to roads and railroads represents a serious obstacle for competitiveness;

(3) the pillars of health and primary and secondary education, higher education and training, and also the technological readiness score is placed above the overall competitiveness rating, which means that the reasons for the underperforming 
Issue no. $25 / 2018$

business sophistication and innovation need to be sought elsewhere, prompting the question in the direction of competitiveness targeted policy.

These findings are reinforced by the 2017 version of the IMD World Competitiveness Yearbook, where Romania ranks $50^{\text {th }}$ out of 63 analyzed countries, showing a similar relative positioning to that depicted by the GCI and the Legatum Prosperity Index $2016^{2}$, which places Romania $50^{\text {th }}$ out of 149 , highlighting social capital and health as the underperforming main areas and the business environment as the best relatively positioned field. The dynamic of Romania's relative positioning is somewhat different from the s exhibited by GCI data, showing consistent accelerated gains in the last years, as detailed in Graph 2 below.

Graph 2: Romania's prosperity ranking (Legatum Prosperity Index)

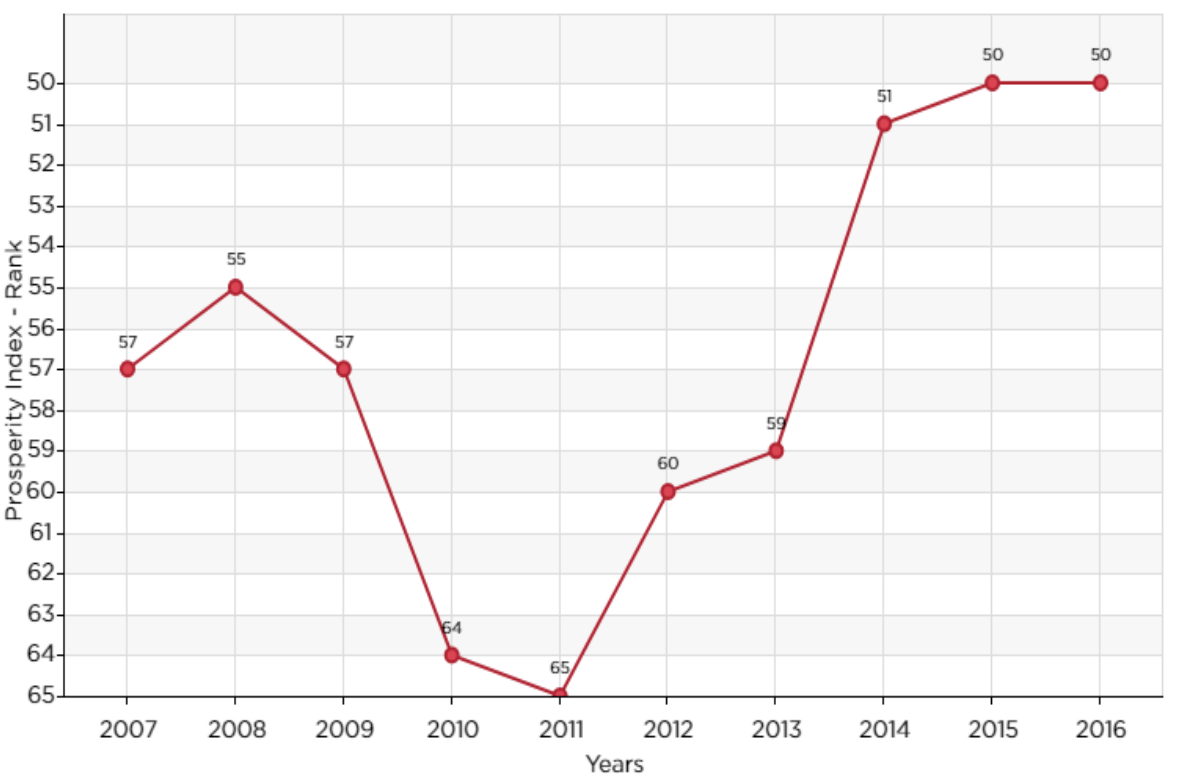

Source: Legatum Institute website, www.prosperity.com

\footnotetext{
${ }^{2}$ Legatum's Institute concept of prosperity is fairly similar to GCI's understanding of competitiveness, thus making comparisons possible. See: www.prosperity.com
} 
Issue no. $25 / 2018$

The picture is complemented by the World Bank's Doing Business in Romania Report and the American Chamber of Commerce (AmCham) Romania 2016 competitiveness report, which bring supplementary elements that help understanding Romania's precise competitive position. The former, i.e. World Bank's Doing Business Report, focuses on the business environment, an important component of competitiveness development. According to this study, Romania ranks in the top $20 \%$, more precisely $36^{\text {th }}$ out of 190 , partly contradicting the theory of Romania's suffocating bureaucracy, a potential hurdle in the quest for competitiveness, especially for SMEs (Corpădean, 2014). On the other hand, AmCham's report, a comprehensive study that looks at Romania's competitive position from six perspectives (general indicators, legislative framework -not indexed-, public administration, physical infrastructure, human resources and fiscal and monetary policy) provides fresh insight on the issue, showing only some minor progress since the previous 2011 report, with three out of the five indexed dimensions registering a positive dynamic (public administration, physical infrastructure, fiscal and monetary policy), but still below EU average, while two of them (public administration and fiscal and monetary policy) scoring above the EU average. It is worth mentioning here that from a CEE comparative perspective, Romania's overall competitiveness score is higher than that of all Eastern Europe's Member States, with the exception of the Czech Republic. 
Issue no. $25 / 2018$

Graph 3: Romanian competitiveness deconstructed (AmCham)

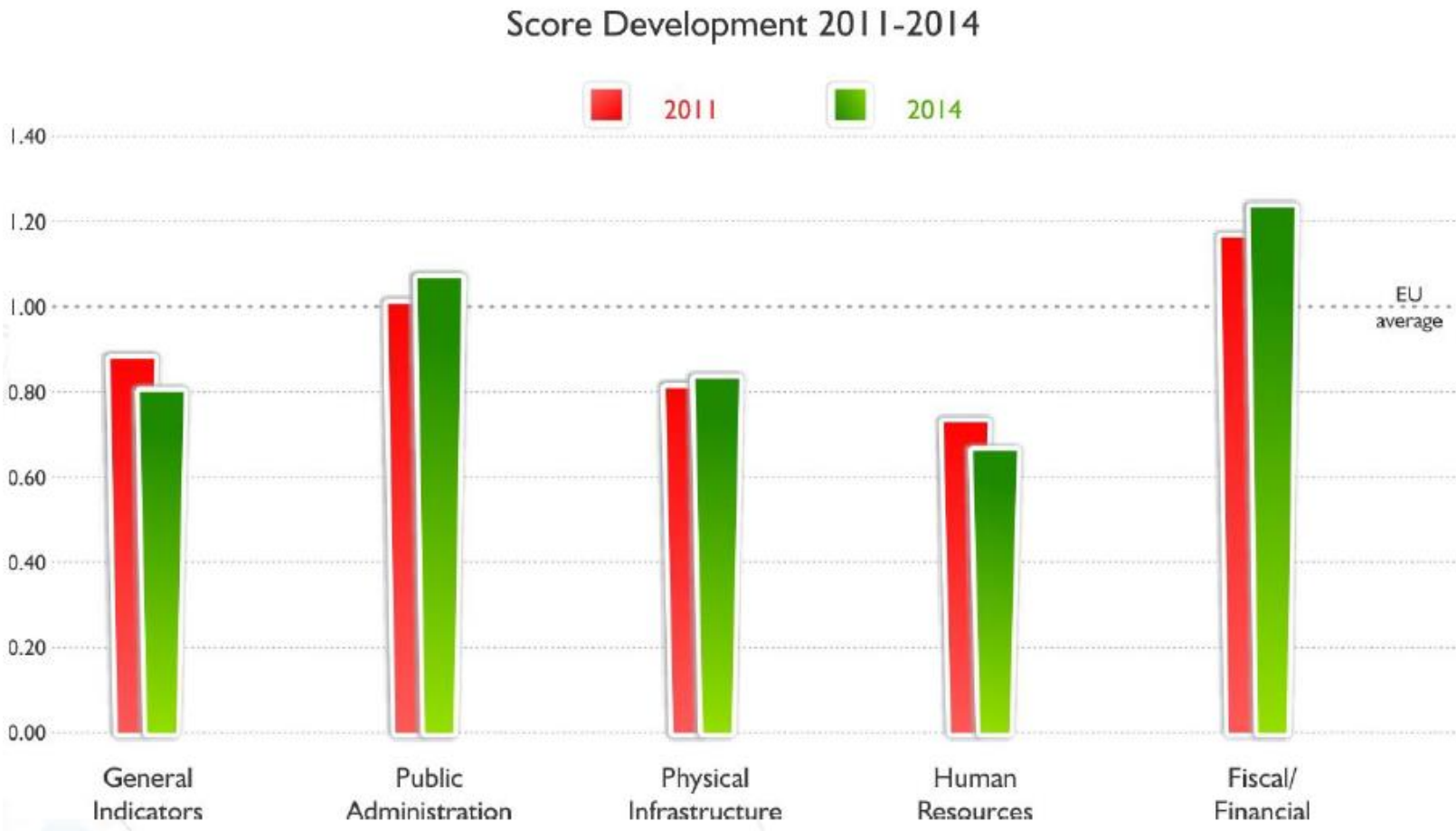

Source: 2016 Romania Competitiveness Report presentation, AmCham, March 29, 2016,

Bucharest.

Breaking down the competitiveness picture, the report highlights 25 areas of competitive advantage, 43 of competitive disadvantage and 15 of a neutral nature. Out of these, the most notable advantages lie in the total public revenue as percentage of GDP (debunking the argument that the main obstacle to public investments and reform is the lack of budget resources and instead pointing towards low efficiency in allocation and implementation), the time needed to start a business, the availability of agricultural land, foreign languages taught at university level, the population's level of health, public debt, as well as several elements pertaining to energy infrastructure. Conversely, among the main competitive disadvantages a couple of domains stand out: tourism, the level of corruption, general governance (with the exception of fighting corruption), transport infrastructure, 
Issue no. $25 / 2018$

education spending levels, innovation, and some elements pertaining to the healthcare system.

In order to underline the impact of all the above mentioned competitiveness facts we are going to present a brief picture of the way in which Romania has succeeded improving the state of its small and medium enterprises (SMEs) sector as an important key factor of interdependence between the level of competitiveness of the organizations and competitiveness of the entire national economy. One of the primary aims of this short insight is to identify and fully understand the necessary future policies needed in order to be able to generate comprehensive approaches to sustain a competitive Romanian business environment based on variables like innovativeness, internationalization, financial indicators and so on. We think that it is very important to present and not to ignore the Romanian SMEs level of competitiveness due to their very important role in enhancing the competitiveness position of the entire national economy. The 2016 SBA Fact Sheet for Romania reveals areas where our country has made significant progresses such as:

- Access to finance which was facilitated by the introduction of financing programs and tax reductions;

- Responsive administration where we can recognize measures like tax reductions and fiscal incentives for individual investors (business angels);

- Also the last noticeable improvement state aid \& public procurement where we can name the reform of public procurement beginning with 2015 reform that was accompanied by two other important financial measures: the 'state aid for SMEs' and the 'supporting investments of SMEs in rural areas.

The same source underlines the fact that criteria's such as: Entrepreneurship, Secondchance, Internationalization, are above or in line with the EU average. The segments that are raising the most important challenges for the Romanian SMEs are represented by Skills \& Innovation where our country it is indicated to be one of the poorest performing country in the EU and also by the Single Market where it is positioned under the EU average. Once having uncovered the main elements behind Romanian competitiveness (and lack thereof), the focus should be on using this information in correlation with existing policy in an attempt to adapt the policy approach in different sectors, as we will attempt in the next chapter. With 
Issue no. $25 / 2018$

this in mind, Graph 4 below lists some of the most poignant obstacles to competitiveness in Romania.

Graph 4: Obstacles to competitiveness in Romania

\begin{tabular}{|l|}
\hline favoritism in decisions of government officials \\
\hline wastefulness of government spending \\
\hline burden of government regulation \\
\hline diversion of public funds \\
\hline corruption \\
\hline insufficient transport infrastructure \\
\hline underdeveloped tourism \\
\hline healthcare system inefficencies \\
\hline low spending on education \\
\hline low efficiency of legal framework in challenging regulations \\
\hline low levels of public trust in politicians \\
\hline
\end{tabular}

low level of business sophistication

low level of innovation

underperforming institutional sector

Source: own analysis based in GCI, AmCham, Legatum, World Bank and IMD reports.

\section{Romanian competitiveness - policy induced or policy deterred?}

The issue of competitiveness is widely discussed today in Romania, at all levels, being them public or private. One of the main resulting documents is the National Strategy for Competitiveness 2015-2020, approved by government decision in autumn 2015 with the task of providing with clear policy guidelines and objectives that would allow policy decisions to improve competitiveness in the following 5 years period. More precisely, several strategic priorities are identified:

- improving regulation (done through to some limited measures regarding taxation, setting up mechanisms that ensure that impact on SMEs is taken into account before passing new laws, improving transparency of public institutions, less bureaucracy, improved access to financing for the private sector),

- promoting public-private partnerships (through institutionalization of research centers in PPP, developing PPPs aimed at improving regulation, development/consolidation of competitiveness clusters), 
Issue no. $25 / 2018$

- aiding factor and support services (through actions among which improving the education system, better correlation between the education system and the labor market, allocating $1 \%$ of GDP for $\mathrm{R} \& \mathrm{D}$, aiding private companies engage in innovation, supporting setting up of companies that operate within the creative industries sector, improving road infrastructure connecting Romania to neighbor countries, extending and improving broad band communication, improving SME density infrastructure,

- promoting 10 viable sectors among which tourism, education, creative industries, health, energy, agriculture, automotive (by increasing investment attractivity and increasing exports),

- preparing the 2050 generation (through actions that include increasing social cohesion, the competitive development of agriculture and rural space and the transition towards a low emissions economy).

However, a closer look at the document reveals that professionally speaking it looks less like a strategy and more like a wish list, as very few concrete measures are defined. Moreover, the numerous (and most of the time vague) objectives indicate that perhaps the purpose of the entire exercise was just to draft a strategy that would capture as many of the existing problems as possible and not to really implement it. This same impression, although maybe not so poignant, emerges when analyzing the current government's 2017-2020 governing program, as measures and their estimated impact seem very loosely correlated. Moreover, the policy proposals, in this form, are prone to severely destabilize the equilibrium between revenues and expenses, reason that makes us think that not all could be implemented, a conclusion that seems to be confirmed by the first three trimesters of 2017 . Not only a series of policies have been scraped (examples include the reduced VAT level for housing transactions, the global revenue taxation system, the pensions system, etc.) but new measures that would supposedly increase immediate government revenues were announced without prior debates involving the main stakeholders. In fact, it can be argued that the most vivid debates are often a reaction to ad-hoc, untested policy decisions, an ex-post character that seriously cripples the overall efficiency of the process. 
Issue no. $25 / 2018$

The instability and still incoherent communication of tax measures to be implemented starting with the next year, not counting the fact that we find ourselves at the end of 2017 and the private environment is already preparing its budgets for the next fiscal year, are important factors determining a series of uncertainties with significant implications on the agents' predictability of the national economic environment. Among the most widely conveyed future measures we can name here the following: application of the split VAT, the transfer of social contributions to the employee, the elimination of the dividend tax or the deduction of VAT. Law no. 177/2017 also brings important changes to the Fiscal Code, among which we can mention here the income ceiling for micro-enterprises, which has been increased from 100,000 Euros to 500,000 Euros. All these hurried measures meant to improve the state of the budget's balance cannot but weaken on the medium and long run the overall situation of the Romanian competitiveness.

Elaborating in the area, we note the highly controversial decision to introduce a split VAT system which would immediately block companies' access to the VAT they collected, thus having a negative impact on cash flows (both their own and their suppliers') and ultimately affecting costs and competitiveness. After initially deciding in early August 2017 (without previously signaling the intention and having any consistent prior debate) a mandatory application for all Romanian companies starting October $1^{\text {st, } 2017}$, the deadline was moved to January $1^{\text {st }} 2018$, with the possibility for companies to opt starting the application in October $1^{\text {st }}$, with a series of fiscal advantages provided as an incentive. Ultimately, only four days before the beginning of the voluntary application period, the budget commission within the Senate has voted for yet another version of the bill, with mandatory application only for companies which are involved in business with the state (starting January $1^{\text {st }} 2018$ ) and voluntary application for all other companies until January $1^{\text {st }} 2019$, when the measure would become compulsory for everybody.

It is obvious that such a degree of policy indecision baffles the private sector, creating distortions due to the high degree of uncertainty that it entails, thus negatively affecting competitiveness. Far from being an isolated event, the split VAT odyssey is just another big impact policy (in)decision, after a complete change of the revenue tax system, announced as a done deal, was (at least for now) scrapped, adding to the impression that fiscal policy lacks 
Issue no. $25 / 2018$

reforms lack solid analysis to back them up. Based on the information provided by the Country Report for Romania 2017, it should be noted that at the moment, the tax compliance is quite low in our country. Romania is registering today the largest VAT gap in the EU, namely the difference between theoretically expected VAT revenues and effectively collected VAT. Moreover, the same source states that the medium-term fiscal strategy does not guide the annual budget process which can generate serious long term implications.

Another yet very controversial decision is the one that will determine an excessively taxation of short-term work contracts beginning with January $1^{\text {st }} 2018$ The issue is having high risk implications that could determine the employers to give up short-time employees and their work to be distributed to full-time employees and will also shift the tax contributions from the employer to the employee, measures that are lacking a natural process of public consultation with the business environment. On the same note the tax base increases by moving contributions to the employee, which allows a lower tax rate to be applied. In this case the salaries in the public sector will not increase even though significant wage increases will occur at the same time, creating even the premises of real wage cuts in the private sector. Without a bill yet, we are discussing today a possible change in the gross salary base and at the same time reducing the cumulative share of contributions from $39 \%$ to $35 \%$, contributions that in this context will fall exclusively on the burden the employee, while reducing concomitantly the income tax from $16 \%$ to $10 \%$.

The relatively recent public debates brought to light a series of other policies with negative implications for the stability and attractiveness of the Romanian business environment, such as the solidarity tax or the elimination of the Pension Pillar II. As a real relevant example it was sufficient to have only the Minister of Finance's statements about the potential intention to remove the pension pillar II to generate serious implications on the capital markets at the time the intentions were communicated to the press. Much has been discussed about a possible tax on companies' turnover, as it may turn out to be a counterproductive measure in view of our desire to encourage the internal economic environment. Not only does it disfavor those businesses that have very large sales volumes and small profit margins but it is also in contradiction with the EU's practice in this area and can significantly affect Romania's competitiveness in the region. Among the recent fiscal 
Issue no. $25 / 2018$

measures that have been already applied is the increase in excise duties on fuels and has been implemented in two stages, the first one from 15 September and the second one from 1 October 2017 in order not to generate a shock on consumption. However, the effects of such a measure are felt to some extent in the cost of the economic agents. Fiscal policies of this nature must be carefully considered as a result of research based decisions on impact studies as they can unbalance the macroeconomic and budgetary stability that Romania has gained over time with a series of significant sacrifices, undermining this way the investors' confidence in the potential future attractiveness of the business environment and consequently decreasing competitiveness.

\section{In a nutshell}

We must acknowledge that most of the interpretations focusing on the realities of the Romanian economy following 1989 were directly or indirectly placed, or at least perceived, as existing only and only under the aegis of a dominant, at that peculiar moment, mainstream of economic thought. The deeply entrenched dogma of building the "multilaterally developed socialism" to be straightforwardly continued by a situation that was depicted as "a true stampede of Western liberalism", sometime even flavored with mimetic libertarian inflexions, all these extremes and whatever stays in between actually co-existed for a while during the early 90 s and then were followed by a sui generis neo Keynesianism that was illustrated by the "stop and go" economic policy discourse of the mid and late "90s. The fact that no clear economic model could decently capture the essence of the Romanian economic environment during transition and even later was quite often attributed to the reality that the domestic political establishment was poorly educated towards market economy mechanisms and, roughly said, too corrupt in order to manage professionally and ethically such a profound task. At this point we believe that managing such a task would mean highlighting by all means the educational track towards an adequate institutional culture, including that forging the delicate area of competition.

Still, what should be accounted during the quarter of century as relevant for the present day economic outlook, generated by the economic policy in place? As the economic realities were observed during the last couple of years, it is obvious that Romania in transition 
Issue no. $25 / 2018$

(1990-2006) had suffered initially from what has been called "loss of momentum", generated by the initial misallocations that were the pre-EU accession period norm. No coherent macroeconomic approach was done, even if possible, in order to counterbalance unilateral moves of the economy, only to be regretted one step further and to be compensated by excessive and unbalanced governmental involvement. Moreover, and a stage later, beyond the plethora of assets it brought to the country by the accession to EU, the process also induced a sort of "new distortion" in allocating resources, which situation at its turn influenced the domestic economic landscape and the international dimensions of the Romanian economy as a whole. There is no school of thought grounded on a clear and consistent doctrine, no matter if of liberal or of conservative consistence that could properly explain the connection between during the economic policies and the emerging results during the last two decades.

Therefore, we strongly believe the only professional way to focus on these issues would be to combine various domains' perspectives and attempt to conclude an aggregate theoretical pattern of interpreting the evolution of the Romanian economy from a cultural angle. Catching historical, anthropological, sociological and overall cultural dimensions and framing them into a model that could be without doubt branded as heterodox, could have a stronger explanatory force for the setbacks and liabilities as observed by so many during the last couple of decades. To what extent such an approach means in fact counter-modeling what has been more or less modeled during time, this would be challenge of an extended future research that has been only sketched in these lines. The challenge has a peculiar consistence: the prospective potential of forecasting consistency, never thoroughly and comprehensively followed to our knowledge, a feature that almost completely lacked from the contemporary Romanian economic life and has to be reinstated. After all, at the peak of the cold war, following a plethora of deep international crises, a situation which has a lot of resemblances with the one today, Furtado (1983) expressed the rationale for an optimist view of the history, a vision that was luckily endorsed in less than a decade. If we could extract, formalize, model and more important institutionalize through the political framework the cultural components that allowed such a foresight to become alive, the future of this country and not only could look much brighter indeed. 
Issue no. $25 / 2018$

It is only because of this fuzzy juncture of the domain of domestic policies, notably in the area of competitiveness that drives us to acknowledge and state the fact that this paper constitutes only a preliminary step of a more comprehensive approach, aimed at fully understanding and assessing the status-quo and politically induced dynamics of the Romanian policy concerning competitiveness. It is our purpose to research on a larger scale and with appropriate means this topic in order to identify paths towards the enhancement of the overall competitiveness of the Romanian economy, especially in the higher added value areas.

\section{References}

- $\quad$ ALBU, L.-L. (2010) Economia la răscruce? Dar ştiinţa economică? In: MALIŢA, M., GEORGESCU, C. (Coord.), România după criză. Reprofesionalizarea, Editura Compania, Bucureşti, pp. 57-62.

- $\quad$ ALIGICA, P.D. (2003), Instituţii, guvernare economică şi performanţă economică în România post-comunistă, In: CIUPAGEA, C., LAZEA, V. (Coord.), Modificări structurale şi performanţa economică în România, I.R.L.I., Bucureşti, pp. 47-69.

- $\quad$ AligiCĂ, P.D., EVANS, A.J. (2009), The Neoliberal Revolution in Eastern Europe. Economic Ideas in the Transition from Communism, Edward Elgar, Northhampton, pp. 48$49 ; 54-55$

- $\quad$ BARNA, R. (2010) Noua paradigmă a dezvoltării în contextual globalizării, EFES, Cluj-Napoca, pp. 73-78.

- $\quad$ BOMPA, T. O., POROJAN, D. (2010) România - acum ori niciodată! Un model de guvernare care salvează România, Editura Irecson, Bucureşti, pp. 164-171.

- $\quad$ BRĂTiAnU, C., VASilache, S., MÂNDRUlEANU, A. (2010) Dinamica integratorilor organizaţionali, Editura Curtea Veche, Bucureşti, pp. 16-28.

- CORPĂDEAN, Adrian-Gabriel (2014) Europe 2020 - An Agenda for Citizens and States, In: NAUMESCU, Valentin (ed), Democracy and Security in the 21st Century: Perspectives on a Changing World, London: Cambridge Scholars, pp. 267-283.

- DADE, P., ROSE, C. (2007) Using Values Modes, [http://www.campaignstrategy.org/articles/usingvaluemodes.pdf] July 8, 2017. 
Issue no. $25 / 2018$

- $\quad$ DAIANU, D. (2000) Incotro se îndreaptă ţările postcomuniste? Polirom, Iaşi, pp. 202-224.

- $\quad$ DIERX, A., ILZKOVITZ, F., PATARACCHIA, B., RATTO, M., THUM-THYSEN, A., VARGA, J. (2017) Distributional Macroeconomic Effects of the European Union Competition Policy: A General Equilibrium Analysis, In: OECD, A Step Ahead. Competition Policy for Shared Prosperity and Inclusive Growth, Washington D.C., pp.155-185.

- DRĂGAN, G. (2013) EU economic governance between the need for reform and the inertia of status quo, In: RADU, L., BÂRGĂOANU, A., CORBU, N. (Eds.), The Crisis of the European Union, Identity, Citizenship and Solidarity Reassessed, Editura Comunicare.ro, Bucureşti, pp. 15-40.

- $\quad$ EHRENBERG, G. R., SMITH, S. R. (2012) Modern Labor Economics. Theory and Public Policy, Prentice Hall, Boston, pp. 423-424. http://fac.ksu.edu.sa/sites/default/files/Modern_labor_economics_theory_and_public_policy _.p.pdf] August 14, 2017

- $\quad$ FUDULU, P. (2003) Sindromul instituţiilor slabe ca efect al decalajului culturalinstituţional, In: CIUPAGEA, C., LAZEA, V. (Coord.) Modificări structurale şi performanţa economică în România, I.R.L.I., Bucureşti, pp. 1-30.

- $\quad$ FURTADO, C. (1983) Viziunea optimistă despre istorie, In: Interdisciplinaritatea în ştiinţele umane, Editura Politică, Bucureşti, pp. 419-456.

- $\quad$ HOGWOOD, B.W., GUNN, L.A. (2000) Introducere în politici publice, Editura Trei, Bucureşti, pp. 24-26.

- $\quad$ KALLAI E., MANIU, M. (2007) Remittances and Incentives to Work in Romania, In: The Future of Europe: Security and Economic Development, Academia de Studii Economice, Bucharest, pp. $205-237$.

- MANN, M. (2015) Ne apropiem de sfârşit, dar al cui? In: WALLERSTEIN, I., COLlinS, R., MANN, M., DERLUGUIAN, G., CALHOUN, C. (2015) Are capitalismul un viitor?, Editura Comunicare.ro, Bucureşti, pp. 129-131.

- NORBERG, J. (2010) În apărarea capitalismului global, Libertas Publishing, Bucureşti, pp. 265-271. 
Issue no. $25 / 2018$

- $\quad$ PĂUN, N. (2009) Viaţa economică a României 1918-1948, Presa Universitară Clujeană, Cluj-Napoca, pp.135-214.

- REGULSKA, J. (1992) NGOs and Their Vulnerabilities during the Time of Transition: The Case of Poland, In: Voluntas: International Journal of Voluntary and Nonprofit Organizations, Vol. 10, No. 1, 23-34

- SCHWAB, KLAUS; SALA-I-MARTÍN, XAVIER (Eds.) (2017) The Global Competitiveness Report 2017-2018, World Economic Forum. 